\title{
THE EFFECTIVENESS OF LEARNING STRATEGIES TYPE OF GIVING QUESTION AND GETTING ANSWERS TOWARD MATHEMATICS LEARNING OUTCOMES IN STUDENS CLASS XI OF SMK NEGERI 1 PUNDONG BANTUL DISTRICT IN EVEN SEMESTER OF ACADEMIC YEAR 2015/2016
}

\author{
Elly Puspitaningsih ${ }^{a}$, Widayati $^{\mathrm{b}}$ \\ Mathematics Education Study Program, University of Ahmad Dahlan \\ Jalan Ringroad Selatan, Tamanan, Banguntapan, Bantul, Yogyakarta \\ aellypuspitaningsih@gmail.com, bummunabilah67@gmail.com
}

\begin{abstract}
This research was done because there are many students who are less active in learning. Students do not want to ask about the material they have not understood that the learning outcomes obtained less than the maximum. This study aims to determine the effectiveness of mathematics learning by using strategies question giving and getting answer compared using expository strategy on learning outcomes math of students in class XI of SMK Negeri 1 Pundong Bantul District even Semester in the academic year 2015/2016. This research design was control group posttest-only design. The population in this research was a class XI TKJ A, XI TKJ B, and XI TITL A student of SMK Negeri 1 Pundong. Samples were taken using random sampling techniques derived class XI TKJ B as an experiment class and class $\mathrm{XI}$ TKJ A as the control class. The data collection is done with test method. Testing instrument using validity and reliability. Data were analyzed using analysis prerequisite test including normality test with Chi-square formula, homogeneity test with Bartlett's test, and hypothesis testing using t-test. Based on calculations with significance level $\alpha=5 \%$ and degrees of freedom of 60 , the conclusion that: (1) there are differences in learning outcomes of students learning math using active learning strategies type of giving question and getting answer by learning to use expository strategies. This is indicated by the results of the first test hypothesis that $t_{\text {count }}>t_{\text {table }}$ that is 2,0678 $>2,0003$.(2) learning to use active learning strategies type of giving question and getting answer more effective than learning to use strategies expository. It is shown from the results of the second test the hypothesis that $t_{\text {count }}>t_{\text {table }}$ that is $2,0678>1,6706$.
\end{abstract}

Keywords: effectiveness, mathematics learning outcomes, giving question and getting answer.

\section{INTRODUCTION}

Mathematics is a basic science, both its applied aspects and reasoning aspects have an important role in the mastery of science and technology. So the importance of mathematics in mastering science and technological development, mathematics learning is included in all levels of education from elementary school to college. Therefore, in every process of learning mathematics that exists at every level of education must be carried out to the fullest. In every learning, it is always expected that students can receive the subject matter well and of course obtain learning outcomes that are suitable with the learning objectives, because the success of the learning process is the main goal in education at school.

In accordance with the results of the interview on October 9, 2015 and October 12, 2015 with the mathematics teacher of SMK Negeri 1 Pundong namely Ibu Rini Astuti, S.Pd. in mathematics learning there are still many students who are less actively involved in learning, only a few students are active in asking questions and are serious about taking lessons and in doing exercises given in groups or individually while other students seem not involved in group discussions or working individual assignments and just chatting outside the issue of discussion, playing mobile phones, and disturbing other friends.

Mathematics learning in class XI of SMK N 1 Pundong used expository strategies. Learning is still teacher centered. Expository strategy is a learning strategy that emphasizes the process of delivering material verbally to students, the teacher explains the learning material in front of the class then gives examples of questions and practice questions. In learning the teacher chooses expository learning strategies with the reason that this strategy is not complicated, not time consuming and the learning 
method can be delivered in a timely manner. This has an impact on students in the involvement of learning to be less than optimal. While the success of a learning is not only influenced by the learning strategies applied but also by the activeness of students to involve themselves in the learning process. Active learning strategies are steps specifically planned to make students actively involved in learning starting from the initial activities to the end of learning.

The giving question and getting answer strategy is an active learning strategy giving questions and receiving answers. According to Zaini, Hisham et al (2002: 71) the strategy of giving question and getting answer is used to involve students in repeating the subject matter that has been delivered. Based on the description, applying the giving questions and getting answers strategy in learning is expected to trigger students to be actively involved in learning and encourage students to want to ask questions and respond to ongoing learning material.

In line with this, Danny Sudayat's (2011) research shows that applying the strategy of giving question and getting answer learning in learning is more effective than applying expository strategies in learning to students' mathematics learning outcomes. In addition, Abdul Fatah's research (2013), shows applying the strategy of giving question and getting answer learning in learning is more effective than applying conventional learning in learning to students' mathematics learning outcomes.

The problems in this research are:1) Is there a difference in the average mathematics learning outcomes of students learning using the giving question and getting answer strategy compared to students who learn using expository learning strategy class XI of SMK N 1 Pundong Bantul District in Even Semester in the academic year of 2015/2016. 2) Is mathematics learning using the active learning strategy type giving question and getting answer more effective than learning that uses expository learning strategies on mathematics learning outcomes of class XI students of SMK Negeri 1 Pundong Bantul Regency in Even Semester in the academic year of 2015/2016.

The objectives of this study are: 1) To determine whether or not there are differences in the average mathematics learning outcomes of students who learn using the giving question and getting answer strategy compared with students who learn using expository learning strategies of class XI of SMK Negeri 1 Pundong Bantul District in Even Semester in the academic year of 2015/2016. 2) To find out whether mathematics learning using the giving question and getting answer learning strategy is more effective than learning using expository learning strategies on mathematics learning outcomes of class XI students of SMK Negeri 1 Pundong, Bantul Regency, Even Semester in the academic year of 2015/2016.

\section{METHODS}

This type of research used a posttest only design control group with one type of treatment (Arifin, Zainal 2012: 78).

Table 1. Research design

\begin{tabular}{clcc}
\hline & Group & Treatment & Posttest \\
\hline $\mathbf{R}$ & Experiment & $X$ & $O_{1}$ \\
$\mathbf{R}$ & Control & - & \\
\hline
\end{tabular}

Information:

Experiment : Classes that use active learning strategies giving question and getting answer

Control : Classes that use expository learning strategies

$\mathrm{R} \quad$ : Random

$\mathrm{X} \quad$ : There is a treatment using active learning strategies giving question and getting answer

- $\quad$ : There is no treatment

$O_{1} \quad:$ Results of the experimental class posttest

$\mathrm{O}_{2} \quad$ : Results of the control class posttest

This research was conducted at SMK N 1 Pundong Bantul Regency in Even Semester in teh academic eyar of 2015/2016. The total number of students in class XI of SMK N 1 Pundong in academic year of 2015/2016 is 248 students consisting of 4 majors namely majors TKJ, TAV, TITL, and TP. The population in this study were class XI TKJ A, XI TKJ B, and XI TITL A SMK N 1 Pundong Bantul 
Regency in Even Semester in the academic year of 2015/2016 with a total of 94 students. While the sample in this study was taken using random sampling technique obtained by class XI TKJ B as the experimental class and class XI TKJ A as the control class.

The data collection technique used was the documentation and test method. The documentation used was in the form of final semester test scores of class XI students of SMK Negeri 1 Pundong to find out about students' initial abilities before the experiment was conducted. The test method is used to retrieve data in the form of students' mathematics learning outcomes after an experiment in which the instruments used are objective multiple-choice questions that have been adjusted based on the problem grid with permutation and combination material.The analysis prerequisite test used is the normality test using Chi-square formula and homogenity test using the Bartlett test. The research hypothesis test used $\mathrm{t}$-test of two tiles or one tile.

\section{RESULTS AND DISCUSSION}

Based on the research that has been done by the researcher, the data obtained in the form of the initial ability and student learning outcomes.

\section{Research Results}

\section{a. Initial ability}

\section{1) Normality testing of initial abilities}

The summary results of the normal ability normality test can be seen in Table 2 .

Table 2. Summary of Normality Ability Value Test Results

\begin{tabular}{ccc}
\hline Class & $\chi_{\text {count }}^{2}$ & $\chi_{\text {table }}^{2}$ \\
\hline Experiment & 4,6307 & 9,4877 \\
Control & 6,6786 & 9,5877
\end{tabular}

From the normality test at a significant level of $5 \%$ and the degree of freedom $=4$, it can be seen that both the experimental class and the value control class of $\chi_{\text {count }}^{2}<\chi_{\text {table }}^{2}$ which means that the data values of the initial ability of the experimental class and the control class are normally distributed.

\section{2) Homogeneity Test of Early Capabilities}

The summary results of the initial homogeneity test can be seen in Table 3 .

Table 3. Summary of Initial Capability Homogeneity Test Results

\begin{tabular}{cc}
$\chi_{\text {count }}^{2}$ & $\chi_{\text {table }}^{2}$ \\
\hline $\mathbf{1 , 2 1 2 5}$ & 3,8415 \\
\hline
\end{tabular}

At a significant level of 5\% and degrees of freedom $=1$, it can be seen that $\chi_{\text {count }}^{2}=1,2125$ and $\chi_{\text {table }}^{2}=3,8415$ so that $\chi_{\text {count }}^{2}<\chi_{\text {table }}^{2}$ which mean both classes have the same variance (homogeneous).

\section{3) Test the Hypothesis of the Meaning of the Average Value of the Initial Capability}

The summary of the results of the first hypothesis testing the initial capability data can be seen in Table 4.

Table 4. Summary of Results of the First Hypothesis Test of Initial Capability Value

\begin{tabular}{cc}
\hline $\boldsymbol{t}_{\text {count }}$ & $\boldsymbol{t}_{\text {table }}$ \\
\hline $\mathbf{1 , 5 3 7 4}$ & 2,0003 \\
\hline
\end{tabular}

At a significant level of 5\% and degrees of freedom $=60$, it can be seen that $\boldsymbol{t}_{\text {count }}=1,5374$ and $\boldsymbol{t}_{\text {table }}=2,0003$ sehingga $\boldsymbol{t}_{\text {count }}<\boldsymbol{t}_{\text {table }}$ which means there is no difference in average student learning outcomes. 


\section{b. Mathematics Learning Results}

\section{1) Normality Test}

The summary of the results of the normality test of mathematics learning outcomes can be seen in Table 5.

Table 5. Summary of Normality Test Results for Mathematics Learning Outcomes

\begin{tabular}{ccc}
\hline Class & $\chi_{\text {count }}^{2}$ & $\chi_{\text {table }}^{2}$ \\
\hline Experiment & 5,5110 & 7,8417 \\
Control & 6,0411 & 7,8417 \\
\hline
\end{tabular}

At a significant level of $5 \%$ and degrees of freedom $=4$, it can be seen that in the experimental class $\chi_{\text {count }}^{2}=4,9440$ and $\chi_{\text {table }}^{2}=5,9915$ so that $\chi_{\text {count }}^{2}<\chi_{\text {table }}^{2}$ which the means the experimental class has data on mathematics learning outcomes that are normally distributed. And in the control class $\chi_{\text {count }}^{2}=6,0411$ and $\chi_{\text {table }}^{2}=7,8417$ so that $\chi_{\text {count }}^{2}<\chi_{\text {table }}^{2}$ which means the control class has data on mathematics learning outcomes that are normally distributed.

2) Homogeneity Test

The summary of the results of the initial homogeneity test can be seen in Table 6 .

Table 6. Summary of Homogeneity Test Results Value of Mathematics Learning Outcomes

\begin{tabular}{ll}
\hline$\chi_{\text {count }}^{2}$ & $\chi_{\text {table }}^{2}$ \\
\hline 1,0695 & 3.8415 \\
\hline
\end{tabular}

At a significant level of 5\% and degrees of freedom $=1$, it can be seen that $\chi_{\text {count }}^{2}=1,0695$ and $\chi_{\text {table }}^{2}=3,8415$ so that $\chi_{\text {count }}^{2}<\chi_{\text {table }}^{2}$ which means the results of learning mathematics both classes have the same variance (homogeneous).

\section{3) Test of One Tail Hypothesis}

The summary results of the one tail hypothesis test of mathematics learning outcomes can be seen in Table 7.

Table 7. Summary of Hypothesis Test Results One Tail Value of Learning Outcomes

\begin{tabular}{cc}
\hline $\boldsymbol{t}_{\text {count }}$ & $\boldsymbol{t}_{\text {table }}$ \\
\hline $\mathbf{2 , 0 6 7 8}$ & 2,0003 \\
\hline
\end{tabular}

At a significant level of 5\% and degrees of freedom $=60$ obtained $\boldsymbol{t}_{\text {table }}=2,0003$ and $\boldsymbol{t}_{\text {count }}=$ 2,0678 seen that $\boldsymbol{t}_{\text {count }}<\boldsymbol{t}_{\text {table }}$ which the means there is a difference in the average student learning outcomes using the giving question and getting answer strategy with learning outcomes of students who learn to use expository strategies in class XI students of SMK Negeri 1 Pundong Bantul Regency in Even Semester in the academic year of 2015/2016.

\section{4) Test of One Tail Hypothesis}

The summary of the results of the second hypothesis test of mathematics learning outcomes value data can be seen in Table 6 .

Table 8. Summary of Second Hypothesis Test Results Learning Outcomes

\begin{tabular}{cc}
\hline $\boldsymbol{t}_{\text {count }}$ & $\boldsymbol{t}_{\text {table }}$ \\
\hline $\mathbf{2 , 0 6 7 8}$ & 1,6701 \\
\hline
\end{tabular}

At a significant level of 5\% and degrees of freedom $=60$ obtained $\boldsymbol{t}_{\text {table }}=1,6701$ dan $\boldsymbol{t}_{\text {count }}=$ 2,0678 seems like $\boldsymbol{t}_{\text {count }}<\boldsymbol{t}_{\text {table }}$ which the meaning of the learning strategy of giving question and getting answer is more effective than the expository strategy on mathematics learning 
outcomes in students of SMK Negeri 1 Pundong Bantul Regency in Even Semester in the academic year of 2015/2016.

\section{Discussion}

Based on the results of data analysis and assumptions above, it can be concluded that mathematics learning using the active learning strategy type giving question and getting answer is more effective than learning that uses expository strategies. This can be seen from the hypothesis test of one party at a significant level of 5\% and the degree of freedom (df) $=60$ which is $\boldsymbol{t}_{\text {count }}=2.0678$ and $\boldsymbol{t}_{\text {table }}=1.671$, so that $\boldsymbol{t}_{\text {count }}>\boldsymbol{t}_{\text {table }}$.

Student activities in learning mathematics by using the giving question and getting answer strategy begin with the teacher explaining the material briefly then giving a pair of cards that are used to write the statements that you want to ask. Students form groups and share their knowledge with each other after learning. In group activities students look active in asking questions and sharing information that they have obtained during learning. Students discuss the statements they have written on the card with other groups. Using the card media students become more active in asking about learning material because with the card all the questions students want to ask are more organized. In addition, students are also given the opportunity to ask questions with their friends who are then asked to the teacher when the existing questions cannot be solved together.

While learning activities that use expository learning strategies also work well. Only in learning it looks more dominated by teachers, because in learning the teacher explains the learning material and students listen to explanations from the teacher. Only a few students who are seen actively participate in learning and are active to ask questions.

From the description above, it illustrates that learning that applies the active learning strategy of the giving question and getting answer type is more effective than learning which the learning applies expository learning strategies to the mathematics learning outcomes of class XI students of SMK 1 Pundong in the academic year of 2015/2016.

\section{CONCLUSION}

Based on the analysis of the experimental data and the discussion, this activity concludes the following:

1. There are differences in the average mathematics learning outcomes of students who learn using active learning strategies type giving question and getting answered and the average mathematics learning outcomes of students who learn using expository learning strategies in class XI students of SMK Negeri 1 Pundong Bantul District in Even Semester in the academic year of 2015 / 2016. This can be seen from the results of the calculation of the value $\left|t_{\text {count }}\right|=2.0678$ and $t_{\text {table }}=$ 2,0003 , then $\left|t_{\text {count }}\right|>t_{\text {table }}$. So that $\mathrm{H}_{0}$ is rejected and $\mathrm{H}_{1}$ is accepted. Thus the first hypothesis has been tested by rejecting $\mathrm{H}_{0}$ and accepting $\mathrm{H}_{1}$.

2. The active learning strategy of the giving question and getting answer type is more effective than the expository learning strategy on the learning outcomes of class XI students of SMK Negeri 1 Pundong, Bantul Regency, even Semester in the academic year of 2015/2016. This can be seen from the calculation of the value of $t_{\text {count }}=2.0678$ and $t_{\text {table }}=1.6701$, then $t_{\text {count }}>t_{\text {table }}$ so that $\mathrm{H}_{0}$ is rejected and $\mathrm{H}_{1}$ is accepted. Thus the second hypothesis has been tested by rejecting $\mathrm{H}_{0}$ and accepting $\mathrm{H}_{1}$.

\section{REFERENCES}

Arifin, Zainal. 2012. Penelitian Pendidikan. Bandung : Remaja Rosdakarya.

Fatah, Abdul. 2013. "Efektivitas Strategi Pembelajaran Aktif Tipe Giving Question And Getting Answer Terhadap Hasil Belajar Peserta Didik Materi Himpunan Kelas VII M. Ts. N. U Mangkang Kulon Tugu Kota Semarang Tahun Pelajaran 2011/2012”. Semarang : Institut Agama Islam Walisongo. Purwanto. 2011. Evaluasi hasil Belajar. Jakarta: Pustaka Pelajar. 
Sudayat, Danny. 2011. "Pengaruh Strategi Pembelajaran Tipe Giving Question And Getting Answer Terhadap Hasil Belajar Matematika Siswa". Jakarta : Universitas Islam Negeri Syarif Hidayatullah.

Sugiyono.2012. Metode Penelitian Pendidikan (Pendekatan kuantitatif, kualitatif, dan R\&D).Bandung: Alfabeta.

Uno, B Hamzah. 2011. Model Pembelajaran Menciptakan Proses Belajar Mengajar yang Kreatif dan Efektif. Jakarta: Bumi Aksara.

Zaini, Hisyam. 2002. Strategi Pembelajaran Aktif. Yogyakarta: CTSD (Center for Teaching Staff Development ) 